\title{
DECOUPLING AT THE MARGIN: THE THREAT TO MONETARY POLICY FROM THE ELECTRONIC REVOLUTION IN BANKING
}

\author{
Benjamin M. Friedman
}

Working Paper 7955

http://www.nber.org/papers/w7955

\author{
NATIONAL BUREAU OF ECONOMIC RESEARCH \\ 1050 Massachusetts Avenue \\ Cambridge, MA 02138
}

October 2000

This paper was prepared for the conference on "The Future of Monetary Policy," sponsored by the journal International Finance, the Financial Vice Presidency of the World Bank, and the Research Department of the International Monetary Fund, Washington, D.C., July 11, 2000. I am grateful to Charles Freedman, Charles Goodhart and Michael Woodford for helpful discussions, and to the Harvard Program for Financial Research for research support. The views expressed in this paper are those of the author and not necessarily those of the National Bureau of Economic Research.

(C) 2000 by Benjamin M. Friedman. All rights reserved. Short sections of text, not to exceed two paragraphs, may be quoted without explicit permission provided that full credit, including $(\mathrm{C}$ notice, is given to the source. 
Decoupling at the Margin: The Threat to Monetary Policy from the Electronic Revolution in Banking

Benjamin M. Friedman

NBER Working Paper No. 7955

October 2000

JEL No. E58

\begin{abstract}
The threat to monetary policy from the electronic revolution in banking is the possibility of a "decoupling" of the operations of the central bank from markets in which financial claims are created and transacted in ways that, at some operative margin, affect the decisions of households and firms on such matters as how much to spend (and on what), how much (and what) to produce, and what to pay or charge for ordinary goods and services. The object of this paper is to discuss how this possibility arises and what it implies, to dismiss as unessential to the argument various extreme characterizations that have arisen in the recent debate on this issue (for example, that no one will use money for ordinary economic transactions), and to address the specific arguments on the issue offered by Charles Goodhart, Charles Freedman and Michael Woodford.
\end{abstract}

\author{
Benjamin M. Friedman \\ Department of Economics \\ Harvard University \\ Littauer Center 127 \\ Cambridge, MA 02138 \\ and NBER \\ bfriedman@harvard.edu
}




\section{What is the Issue?}

The prospect that electronic advances in banking practices may present complications for central banks, perhaps to the point of threatening the efficacy of monetary policy influence over inflation and economic activity, has now attracted widespread attention. As is often the case when the matter at issue is a threat that lies mostly in the future, however, there is much confusion over just what the potential problem is. Parts of the recent discussion have addressed possibilities that, while conceivable enough as a theoretical matter, never had much prospect of coming into reality to begin with (at least not within the now foreseeable future). As a result, much of this discussion has failed to address those concerns that more plausibly threaten some central banks' ability to carry out an effective monetary policy over a horizon of, say, the next quarter century.

It is therefore useful to begin by noting, in a few particulars, what is not the plausible source of concern: It is not the possibility that nobody will use currency for ordinary economic transactions, nor that no one will use bank checks to execute transactions. It is not that no bank will hold balances at the central bank. It is not that the central bank will be unable to control the size of its own balance sheet. It is not that the central bank will be unable to influence the price

— that is, the interest rate - at which its own liabilities exchange for other claims that private transactors regard as assets. Finally, the issue is not that the central bank will be unable to influence some short-term nominal interest rate.

What, then, is the issue? Broadly stated, the question in the first instance is whether technological innovations will impair the central bank's ability to carry out operations that 
reliably affect economic activity in the usual sense of real output and/or price inflation (I state the matter in this way in order to abstract from doctrinal issues of monetary neutrality — in other words, whether monetary policy affects prices directly or only by affecting real spending and output). But if this is the question that ultimately motivates the discussion, why isn't the operational issue, the analytical possibility to be addressed, any of the half dozen specifics stated just above?

The threat to monetary policy from the electronic revolution in banking is the possibility of a "decoupling" of the operations of the central bank from the markets in which financial claims are created and transacted in ways that, at some operative margin, affect the decisions of households and firms on such matters as how much to spend (and on what), how much (and what) to produce, and what to pay or charge for ordinary goods and services. The list of extreme circumstances noted above, which seem to capture the imagination in much of the discussion of this issue - nobody will use currency, and so on - would of course be sufficient to bring such a decoupling about. But they are no more necessary in this context than they are likely to occur. The threat to monetary policy is more subtle.

\section{Decoupling at the Margin}

The idea of "decoupling" in this context bears some explanation. All standard theories of how monetary policy works have some explicit coupling mechanism that connects the purely financial operations of the central bank to the nonfinancial decisions made by households and firms: For example, banks are legally required to hold reserves at the central bank in order to 
issue the claims that the public uses for everyday transactions. Or, banks are required to hold reserves at the central bank in order to create money, which doesn't matter in and of itself; but only by issuing money can banks create the credit that the public needs. Or, banks have to hold settlement balances at the central bank in order to carry out their business, and the settlement balances needed are monotonically related to the banks' own size of operations. Each of those stories has in it a mechanism that links the operations of the central bank not just to financial quantities, interest rates and other asset prices but, via well understood accounts of household and firm behavior, to the evolution of real output and prices in the nonfinancial economy.

What, then, would "decoupling" mean in this context? There is both a quantity and a price interpretation.

The quantity interpretation is that at the margin increases or decreases in the size of the central bank's balance sheet, which the central bank can of course bring about at its discretion, become less tightly (in the limit, not at all) related to increases or decreases in the volume of assets and liabilities that the public needs to carry out its own business - namely, money and credit. For this notion to have practical relevance, the idea that it applies at the margin of expansion or contraction is crucial. It has long been known (the classic reference is to Tobin and Brainard) that the size of the central bank's balance sheet does not matter in this context. What matters is the relationship not at the average but at the margin of expansion or contraction. To anticipate the discussion below of Charles Goodhart's argument, whether there are two drug dealers who have to use currency for the anonymity it provides or two thousand, or even two million, is not the cutting edge of the issue. What matters is, instead, how closely the expansion 
or contraction of this activity requiring currency matches the expansion or contraction of the overall economy that the central bank seeks to influence.

Alternatively, the price (or interest rate) interpretation of what it would mean to "decouple" the central bank's operations from the expansion or contraction of the economy is that the interest rate that the central bank can set, on the exchange of its own liabilities for other claims, becomes less tightly (in the limit, not at all) connected to the interest rates and other asset prices that matter for ordinary economic transactions. Some specific examples may help to illustrate the central idea. One is the loan-shark industry, in which some lenders charge, and some borrowers pay, extremely high interest rates compared to prevailing rates in more conventionally constituted credit markets. The interest rate in this market is simply not connected in a meaningful way to the rest of the financial world; in technical terms, it is an outcome determined by the actions of decision-makers who are at a corner solution.

A second example: Within the past year, in the United States, an unusually wide spread has opened up between the interest rate on long-term U.S. Treasury securities and interest rates on similar instruments like high-grade corporate bonds and securities collateralized by insured mortgages. The apparent reason is the projected scarcity of long-term Treasury bonds. If the U.S. Government continues on its currently projected path, in which all outstanding Treasury obligations are to be retired within another decade or so, this scarcity value will become progressively greater. When there is only, say, $\$ 100,000$ of long-term Treasury bonds left outstanding, it will be very easy for the Federal Reserve — or anybody else, for that matter — to drive the interest rate on these bonds arbitrarily close to zero (or even below zero, should anyone 
choose). But by that time this interest rate will have become completely disconnected from the interest rates that matter for the public's ordinary economic transactions.

Students of monetary policy have long understood that the coupling, at the margin, of operations by the central bank and the decisions of households and firms is crucial to monetary policy influence over output and/or prices. The issue today is whether new technological developments, over the foreseeable future, may plausibly threaten a "decoupling at the margin." In Friedman (1999), I have argued that this prospect is one that deserves to be taken seriously. In the remainder of this paper, I shall address the counter-arguments presented by Charles Goodhart, Charles Freedman and Michael Woodford.

\section{Goodhart: The "One Drug Dealer" Argument}

The backbone of Charles Goodhart's (2000) case is what I call the "one drug dealer" argument. At some level, it is surely right. There will always be some drug dealer, or other law breaker, who insists on using currency in order to preserve the anonymity of his or her criminally prosecutable activities. The demand for currency — hence for central bank liabilities — will not disappear.

The issue, however, is whether this matters at the relevant margin. I believe not. There are also people willing to pay up for buffalo nickels, liberty head dollars, and other coins valued for numismatic reasons. But this doesn't matter for the conduct of monetary policy either. Such demands are simply decoupled from the margins of expansion or contraction that affect ordinary macroeconomic activity. The prices of these items are, in effect, corner solutions. 
Moreover, as Charles Freedman usefully points out, for the central bank to fix the supply of currency, rather than passively accommodating currency demand, would represent a way of conducting monetary policy quite different from what actual central banks now do or within living memory have done. (The footnote in Freedman (2000) to the effect that currency typically plays only a passive role in monetary policy implementation should be required reading in all courses on macro- or monetary economics.) Goodhart also acknowledges the prospect of ebalances taking the place of bank checking accounts, and I regard this possibility as closer to the heart of the issue. The question here, as he clearly recognizes, is whether the claims people exchange in order to execute transactions will continue to be claims on the books of banks (or, equivalently, claims backed one-for-one by bank deposits). The possibility that this may cease to be true is a key part of the threat that the e-revolution presents for monetary policy.

Here too, however, the argument that matters must be one at the margin. The real question is not whether bank deposits will disappear altogether, but whether plausible alternatives not backed by bank deposits (stored value cards, credits on the books of the telephone company, and so on) will weaken the connection between the expansion or contraction of reservable bank deposits and the expansion or contraction of economic activity to an extent that threatens the efficacy of monetary policy.

As Goodhart mentions, and as Michael Woodford emphasizes as well, in theory one can always get around this problem by simply defining as a bank, for purposes of meeting reserve requirements, any entity in the business of providing such claims: the telephone company, the New York City subway system, Microsoft, in principle any firm whose product would be in sufficiently broad demand to render its liabilities generally valued. In Friedman (1999) I 
considered the possibility of a race between regulators seeking to contain this activity within the fence of such regulation and innovators seeking to escape it. I am skeptical of the regulators' prospects for success.

Goodhart mentions, but only in passing (quoting Mervyn King, who in turn mentions the idea only in quoting Jerry Jordan), a potential solution that I suspect has a greater likelihood of success: requiring all government tax payments to be made in central bank liabilities. (A more workable form of this idea, I believe, would be to require that tax payments be made by checks against reservable bank deposits.) Tax payments in most modern economies do not constitute a small, potentially isolated market likely to end up as part of some corner solution. Most firms and most individuals pay taxes, many in sizeable amounts compared to their incomes or profits. Requiring them to do so in bank checks might go a substantial way toward keeping the demand for conventional "money" — and hence for central bank liabilities — coupled to the expansion or contraction of economic activity.

Finally, parts of Goodhart's argument seem to endorse a view that my argument in Friedman (1999) is clearly aimed against: that the central bank needn't do anything; that a mere expression of intentions is sufficient. The most fundamental point of Friedman (1999), which is independent of the setting of the current discussion focused on concerns stemming from the electronic revolution, is that stated intentions matter only if there is something credible to back them up — and, moreover, that whether the central bank can or can't back up its intentions is a matter of institutional arrangements, subject to change. The image that I used to dramatize this point (taken from a film of many years ago) is that of the twelfth-century Chinese emperor Wang Wei-shao composing a poem in elegant Chinese calligraphy and explaining that the poem, if read 
carefully enough to catch the subtle nuance, expresses his displeasure with the Mongol barbarians who are currently creating a disturbance on the Chin empire's western frontier and, further, that this veiled expression of disapproval on his part will be sufficient to cause the barbarians to desist and go away. The point of the story is that Wang Wei-shao was the emperor defeated by Genghis Khan. There may once have been a time when a subtle poem in an emperor's elegant calligraphy was sufficient to make attackers break off, but by Wang Weishao's day that time had obviously passed.

The generic point applies to central banks as well. Alan Greenspan is not the Wang Weishao of the twenty-first century. But circumstances change, especially when political institutions and advancing technology are central to the issue. Expressions of intent on the central bank's part may be sufficient if there exists the capacity to back them up. Moreover, if everybody has grown up in a world in which that capacity existed, they may continue for some time to behave in the same way even after it has atrophied or disappeared. But eventually objective reality catches up.

\section{Freedman: The Central Bank as Settlement Agent}

Charles Freedman (2000) focuses on an aspect of the e-revolution that I regard as a more plausible threat to the efficacy of monetary policy than the possibility that currency might disappear: the possibility that banks' demand for central bank liabilities, for use as settlement balances, may wither. There are two questions here. One is whether the central bank will continue to have enough of a natural advantage in the provision of net interbank settlement services so that banks will always need central bank liabilities for this purpose - and, if not, 
whether regulation can solve the problem. And second, will the use of non-bank claims (what Freedman calls "network money," as distinct from stored-value cards) weaken the link between the terms on which banks hold their settlement balances and what goes on in the rest of the economy?

It is again important to emphasize that nobody denies that the central bank can determine the quantity of claims outstanding on its own balance sheet, or the interest rate at which those claims exchange for something else. The issue is one of decoupling at the margin: whether the expansion or contraction of that quantity, or the increase or decrease of the exchange rate on central bank liabilities against some other asset, would continue to be connected to the expansion or contraction of economic activity and to the broader constellation of interest rates and asset values that matter for this purpose.

Freedman's chief conclusion is that other mechanisms will not replace central bank settlement balances. He provides a good account of how central banks historically came to provide interbank settlement services and the current advantages that central banks currently enjoy in this respect (most prominently, protection against default risk). What is at issue is whether these factors will continue to be decisive in the future, and, moreover, whether they will be sufficient to keep the central bank's balance sheet coupled at the margin to what the general public uses to execute transactions.

On the assumption that banks do continue to want to hold central bank balances, either to execute interbank settlements or for any other purpose, Freedman then sees the relevant interest rate set by "an infinitely elastic provision of loans and deposits" (emphasis added). As will emerge in the discussion below, this seems to me precisely the point. 


\section{Woodford: How Big is Big Enough?}

Before turning directly to the infinite-elasticity issue in the context of Michael Woodford's (2000) argument, however, it is necessary to take issue with several aspects of Woodford's framing of the subject under discussion. To begin, Woodford states that there are two propositions under debate here, one of which is "the premise that improved methods of information processing should substantially or even completely eliminate the need to hold base money." I disagree. As is the case for Charles Goodhart's central argument, putting the matter in this way makes it sound as if what applies here is an argument at the average. The important question is instead whether the need to hold central bank liabilities (base money) remains coupled, at the margin of expansion or contraction, to what is happening to ordinary economic activity. Elimination of the demand for central bank liabilities would of course result in decoupling at the margin, but eliminating this demand altogether is certainly not necessary for such decoupling to occur. Since no one regards the total elimination of demand for central bank liabilities as a plausible possibility within the foreseeable future, framing the matter in these terms diverts attention from the question that is genuinely at issue.

In the same vein, Woodford also misstates the context of this discussion by saying that concerns over the implications of electronic technology for monetary policy rest on "the common assumption that the effects of monetary policy depend on a mechanical connection between the monetary base and the volume of nominal spending." Twenty years ago, many economists indeed thought in terms of such a mechanical connection from the monetary base to nominal spending. (None of Freedman, Friedman, Goodhart and Woodford ever did.) Today almost no one does. To think that there is a process, which researchers can model, by which movements in 
one quantity are systematically though imperfectly related to movements in another quantity is not the same as positing a simple mechanical connection. What matters is whether the movement of one quantity, which the central bank can control, has predictable effects on the movement of another quantity, which the central bank seeks to influence.

Woodford goes on to identify what he calls three "misconceptions," of which I believe two do not apply to the argument at hand. First, Woodford says that the argument for a threat to the efficacy of monetary policy is based on the "failure to recognize that the central bank only needs to be able to control the level of short-term nominal interest rates to achieve its stabilization goal." The issue, however, is whether the central bank can control the rates that matter for influencing economic activity — that is, interest rates that are coupled to the markets that count for this purpose. Control over interest rates that represent corner solutions in isolated, decoupled markets is not sufficient.

The second misperception that Woodford alleges is "the apparent assumption that the use of currency for retail transactions is important for the monetary transmission mechanism." As the discussion above makes clear, however, little or none of the argument here has to do with currency. The far more serious issue here is the emergence of potential alternatives to reservable bank money for use in ordinary transactions, or potential alternatives to central bank balances for interbank settlements.

But the third of what Woodford calls "misperceptions" is crucial: in particular, "the assumption that in order to tighten policy — raising overnight interest rates — the central bank must ration bank reserves, making reserves scarce enough for banks to hold the remaining supply even though the opportunity cost of holding reserves has risen." (I would prefer to state the idea 
in terms of banks being willing to hold no more than the remaining supply of reserves, precisely because the opportunity cost has risen; but it is clear enough that this is what Woodford means.) This process, relying on the balance of supply and demand in the market for central bank liabilities (abstracting from currency, the market for bank reserves) to set the interest rate at which those liabilities exchange for some other claim, indeed stands at the center of most standard models of how monetary policy affects economic activity. Moreover, Woodford is also correct in noting that the point of entry for the central bank in such models is its monopoly power over the supply of its own liabilities. (I likewise emphasized this monopoly power in Friedman (1999); see the section headed "The Central Bank as Monopolist.")

Woodford usefully goes on to point out that conventional analysis of this process assumes a zero rate of interest on reserves (I would say merely a fixed rate; it doesn't have to be zero). Then the main substance of his argument contrasts movements in market interest rates that simultaneously represent movements in the spread of market rates over the rate that the central bank is paying on reserves, versus movements in market interest rates that parallel movements in the rate paid on reserves at a constant spread. This fundamental distinction thus takes the argument into new conceptual territory. In effect, Woodford, like Charles Freedman, is describing a world in which the central bank anchors the entire structure of interest rates by being willing to lend to the private economy (via the banks) in potentially infinite volume Freedman's "infinite elasticity" - and likewise being willing to borrow from the private economy (again via the banks) in potentially infinite volume. In Woodford's terminology, taken from New Zealand, the rate at which the central bank lends is the "borrowing rate" and the rate at which it borrows is the "deposit rate." 
I agree that this procedure should work to anchor an interest rate - and, indeed, an interest rate that is not decoupled in the sense developed above. The new issue that then arises, however, is whether this procedure will involve the central bank in potentially very large transactions. The original point from which I began in Friedman (1999) was the puzzle that the central bank in a country like the United States can establish interest rate levels in markets in which trillions of dollars of trading take place every day, and in which the outstanding volumes of potentially tradeable securities are in the tens of trillions of dollars, by means of transactions often amounting to only a few hundred millions of dollars, and accumulating over an entire year into only a few billions. (See Table 1 in Friedman (1999) for comparisons to other countries.)

Nobody should doubt that a large enough borrower or lender, willing to enter into transactions in infinite volume, can set market rates. (As Goodhart points out, there are problematic fiscal implications of a government agency's being an infinite borrower or lender for reasons not tied to profit maximization or even to a break-even constraint.) What is surprising about Woodford's argument is the apparent fact that in practice, in countries like Australia, Canada and New Zealand, which carry out monetary policy in this way, a procedure that in principle rests on the willingness to lend to or borrow from the market in potentially infinite volume still works on the basis of only tiny transactions.

How can this be true? One possibility, which Woodfern recognizes, is that perhaps the central bank always just happens to choose the interest rate that the market would choose anyway. He rejects this answer as implausible. I agree.

Woodford instead offers an argument to the effect that the central bank can do this because the market has no "inherent equilibrium" interest rate to which it would tend on its own without 
central bank intervention. He rests this argument on the idea that there is "no meaning to the value of the dollar apart from what the Federal Reserve defines it to be." It therefore follows that the Federal Reserve can establish the rate at which the dollar exchanges for other assets, including debt instruments.

Although this argument is of course correct in some contexts, it is not persuasive here. It is essentially an argument about the value of nominal claims. Because the central bank can control the rate at which nominal claims against itself expand, in principle it can also set the rate at which those claims depreciate in real terms. And because a nominal interest rate equals the corresponding real interest rate plus the expected rate of that depreciation, over any time horizon for which inflation expectations are adjustable and expectations are satisfied on average the central bank can therefore make the nominal interest rate whatever it wants. But for short time horizons - as here, where the discussion is mostly about overnight interest rates expectations of price inflation are effectively given, and so what is at issue is movements in real interest rates. Moreover, Woodford's point is about joint movements in the entire constellation of real interest rates, rather than a movement in any one rate versus any other. To repeat: an entity willing to borrow or lend in infinite volume presumably can set the entire structure of real interest rates at whatever level it chooses. But how can a central bank achieve this end by means of only very small transactions compared to the size of its economy or its financial markets?

Woodford seeks to make this idea plausible by appealing to the Keynesian idea that the (real) interest rate is indeterminate along the saving-equals-investment schedule (the IS curve), so that the central bank in this framework is free to establish the interest rate (which is a real rate when inflation expectations are taken as given) wherever it wants by appropriately positioning the 
portfolio equilibrium schedule (the LM curve). Hence until the central bank enters the picture, the market has no "inherent equilibrium" interest rate.

But the money demand function in this Keynesian analysis is defined for a zero (or at least a fixed) interest rate paid on holdings of money. If the own-rate on money balances is varying exactly in step with the return on alternative assets, the interest rate term drops out of the money demand function, and the resulting portfolio balance schedule becomes vertical in the usual space comparing the interest rate to the level of economic activity. To be sure, a vertical portfolio balance schedule can also establish the interest rate level in this framework. But in contrast, the whole point of Woodford's (and Freedman's) argument is that by lending at the "borrowing rate" and borrowing at the "deposit rate" — when the two are close together — the central bank in effect imposes on the economy a portfolio balance schedule that is approximately horizontal.

How, then, can the central banks of Australia, Canada, and New Zealand manage to set their respective economies' nominal short-term interest rates without having to engage in more than tiny transactions? I suspect the answer is a version of the Wang Wei-shao story: market participants know that under current circumstances the central bank can make the interest rate whatever it wants - if necessary, by engaging in very large transactions - and as a result those large transactions are not necessary. The market watches the central bank's signals, and then establishes, (mostly) on its own, the interest rate level that the central bank seeks.

What Goodhart calls "open mouth policy" therefore works: "Because the other players in the money market, whether banks or not, know that the Central Bank has the power of the government behind it, it is actually unlikely that the Central Bank will normally have to 
undertake a large volume of open market operations to get the market to adjust interest rates in line with its wishes. Open month policy will normally suffice" (emphasis added). As Woodford puts the same point, “Thus under a 'channel' system like New Zealand's, changes in the level of overnight interest rates are brought about by simply announcing a change in the OCR [the official cash rate]" (emphasis added).

But what if the market loses its presumption that the central could, or would, be able to do the job if the market did not simply act on its signals? With nothing to back up the central bank's expressions of intent, I suspect that in time the market would cease to do the central bank's work for it. This prospect is ultimately what the threat posed to monetary policy by the electronic revolution is all about.

\section{$\underline{\text { References }}$}

Freedman, Charles. 2000. "Monetary Policy Implementation: Past, Present, Future: Will the Advent of Electronic Money Lead to the Demise of Central Banking?" International Finance, this issue.

Friedman, Benjamin M. 1999. "The Future of Monetary Policy: The Central Bank as an Army with Only a Signal Corps?” International Finance, 2 (November), 321-338.

Goodhart, Charles A.E. 2000. “Can Central Banking Survive the IT Revolution?” International Finance, this issue.

Woodford, Michael. 2000. "Monetary Policy in a World Without Money." International Finance, this issue. 